Open Access

\title{
Study on the promotion effect of informationization on entrepreneurship: an empirical evidence from China
}

\author{
Longpeng Zhang ${ }^{1 *}$ D, Wei Jiang ${ }^{2}$ and Zhiwei Tang ${ }^{1}$
}

\author{
*Correspondence: zlpbobo@126. \\ com \\ ${ }^{1}$ School of Public Affairs and \\ Administration, University of \\ Electronic Science and Technology \\ of China, Chengdu 611731, People's \\ Republic of China \\ Full list of author information is \\ available at the end of the article
}

\begin{abstract}
With the in-depth development of informatization, the role of new ventures and small and micro enterprises in economic growth has become increasingly prominent. However, rare literature systematically studies the impact of informatization on entrepreneurship. Based on the data from the 2011 China Household Finance Survey and the Report of China Informationization Development Assessment (2013), this paper uses the probit model, the multiple-choice probit model, and the Heckman two-stage model to examine the influence of informationization on entrepreneurial choices and entrepreneurial performance. The research finds the following conclusions. Firstly, informationization not only significantly improves the probability of entrepreneurship, but also facilitates the realization of income and employment effects from entrepreneurship. Secondly, information infrastructure, government informationization, and resident informationization, as informationization dimensions, can significantly increase the probability of entrepreneurship, although enterprise informationization plays an opposite role. Finally, the influence of informationization on promoting entrepreneurship varies with entrepreneurial type and entrepreneurial industry.

Keywords: Informationization, Entrepreneurial choices, Entrepreneurial performance, Promotion effect
\end{abstract}

\section{Introduction}

Entrepreneurship is always regarded as an important economic growth driver, which plays its role through intermediate channels such as innovation, competition, diversity, knowledge spillover, and entrepreneurs (Audretsch \& Keilbach, 2004; Carree \& Thurik, 2005; Holcombe, 1998). This has been supported by evidence given in many empirical studies (Audretsch \& Keilbach, 2004; Martin, Picazo, \& Navarro, 2010; Mueller, 2006; Stam \& van Stel, 2009; Valliere \& Peterson, 2009; Wong, Ho, \& Autio, 2005). Therefore, as China experiences economic slowdown and transformation, a move toward entrepreneurial economy is of practical significance to its economic growth. The Chinese government has put forward a national strategy of "mass entrepreneurship and innovation" along with a series of policies to promote innovation and entrepreneurship. However, judging from the realities about entrepreneurship, China still stays at a low entrepreneurial level. According to the survey of "Global Entrepreneurship Monitor", the global entrepreneurship rate steadily increased from $8.9 \%$ in 2001 to

(c) The Author(s). 2019 Open Access This article is distributed under the terms of the Creative Commons Attribution 4.0 International License (http://creativecommons.org/licenses/by/4.0/), which permits unrestricted use, distribution, and reproduction in any medium provided you give appropriate credit to the original author(s) and the source, provide a link to the Creative Commons license, and indicate if changes were made. 
$13.2 \%$ in $2015 .{ }^{1}$ In the meantime, the entrepreneurship rate of China was fluctuating and low performing. In 2015, the entrepreneurship rate of China was $12.8 \%$, which was $3.1 \%$ and $18.8 \%$ lower than the global level and the level of developing countries, respectively. Prieger, Bampoky, Blanco, and Liu (2016) held that each economy has an optimal entrepreneurship rate at different stages of development and that any actual entrepreneurship rate that deviates from the optimal level will put a brake on economic growth. They measured the optimal entrepreneurship rates of countries with different income levels based on "Global Entrepreneurship Monitor." The result showed that the optimal entrepreneurship rate for middleincome countries is $25.1 \%$ (Prieger et al., 2016). According to the classification of the World Bank, China is a country with average or above income. It can be inferred that the current entrepreneurship rate of China is far below its optimal level. There is no doubt that improving the entrepreneurial level of China is a realistic issue worth being studied deeply.

To this end, it is necessary to study the factors influencing entrepreneurship in order to develop targeted entrepreneurial promotion policies. In this information age, we need to explore the path to enhance entrepreneurship from the perspective of informationization. Informationization is a historical process in which information technology is fully exploited and information resources are developed and utilized to promote information exchange and knowledge sharing, increase the quality of economic growth, and boost economic and social development transformation. On the one hand, informationization, to a certain extent, weakens the scale advantage of large enterprises and allows more flexible small enterprises to grow and develop in the new economy (Prieger et al., 2016), which provides a favorable environment for entrepreneurship. From the perspective of transaction costs, informationization helps enterprises participate in market activities with lower transaction costs, saving them from attempt to reduce transaction costs through vertical integration, scaling up, hiring more employees, and building their own suppliers and distributors. They can be run at small size. In addition, from the perspective of agency cost, informationization reduces the costs of acquiring and analyzing information and the agency cost for enterprises. It also makes it easier for managers to supervise more employees, thereby reducing the number of middle management and clerks needed and thus the corporate size. All in all, informationization has an important effect on the behavior of market players in economic and social activities and the organizational form in the market, and significant entrepreneurial opportunities emerge. On the other hand, a number of new systems, new business types, new platforms, and new industries which are spawned by informationization provide institutional, technical, talent, capital, information, professional services, and other elements to support entrepreneurship, which lowers the threshold for entrepreneurship and creates a good business environment. Informationization not only creates abundant entrepreneurial opportunities, but also provides convenient entrepreneurial conditions. With the in-depth development of informationization, contributions of new ventures and small and micro enterprises to economic growth will

\footnotetext{
${ }^{1}$ According to "Global Entrepreneurship Monitor," entrepreneurship rate is defined as the proportion of early entrepreneurs or new business owners in the 18-64 age group.
} 
become increasingly significant. Hence, it is particularly important to deepen the understanding of informationization and entrepreneurship.

This paper studies the influence of informationization on entrepreneurship based on information measurement indexes. The informationization level of China is measured from indexes of information infrastructure and the extent and benefits of information and communication technology applications. This paper also decomposes informationization into information infrastructure, government informationization, resident informationization, and enterprise informationization and examines their influence on entrepreneurship. It also goes further to discuss the heterogeneous effects of informationization on entrepreneurship and the relationship between informationization and entrepreneurial performance. This research not only enriches the understanding of informationization and entrepreneurship, but also has important implications for promoting the move toward entrepreneurial economy in China.

\section{Literature review}

At present, numerous literatures have explored the impact of macroeconomic factors on entrepreneurship, such as economic development (Prieger et al., 2016), industry agglomeration (Brunello \& Langella, 2016), public finance (Darnihamedani, Block, Hessels, \& Simonyan, 2018; Islam, 2015), and institutions (Bosma, Content, Sanders, \& Stam, 2018; Chowdhury, Audretsch, \& Belitski, 2019). Particularly, in the age of informationization, scholars also notice the effect of informationization on entrepreneurship. They mainly study this topic in three aspects: information infrastructure, the utilization of information technology, and female entrepreneurship.

Firstly, the influence of information infrastructure on entrepreneurship has attracted the attention of many scholars. Based on the data about German counties from 2000 to 2005, the research of Audretsch, Heger, and Veith (2015) indicates that strengthening broadband infrastructure can help increase entrepreneurship rate. Cumming and Johan (2010) analyze the data from Canada and find that rural communities with broadband internet have more entrepreneurial activities than those without. Gillett, Lehr, Osorio, and Sirbu (2006) draw the same conclusion as Cumming and Johan (2010) from the data about the USA. Recently, the research of Prieger, Lu, and Zhang (2017) also supports that broadband infrastructure facilitates entrepreneurship and there are complementarities between broadband, transportation, and intellectual infrastructure in promoting entrepreneurship. In general, scholars believe that broadband infrastructure is an important factor in promoting entrepreneurship. However, broadband infrastructure is only an important aspect of information infrastructure. Existing literature does not comprehensively measure information infrastructure. The studies mentioned above to be further expanded and improved to fully understand the impact of information infrastructure on entrepreneurship.

Secondly, existing research also studies the relationship between the utilization of information technology and entrepreneurship. Hanoteau and Rosa (2019) explain the difference in entrepreneurial levels between countries from the perspective of information technology application. Further international empirical research also shows that information technology usage is an important factor that promotes entrepreneurship. Based on the data from China, Barnett, Hu, and Wang (2019) and Zhang and Li (2018) argue that cell phone ownership and Internet use have positive impacts on entrepreneurship 
and the information technology usage can promote entrepreneurial performance. The studies of Asongu and Nwachukwu (2018) and Asongu, Nwachukwu, and Orim (2018) indicate that information technology usage improves openness and institutional quality to promote entrepreneurship in sub-Saharan Africa. In addition, the use of information technology has created new forms of entrepreneurship, for instance, digital entrepreneurship (Nambisan, 2016). However, these studies ignore the application of information technology by different entities such as government, residents, and firms. Information technology applications of different entities may have different impacts on entrepreneurship.

Finally, other scholars focus on the influence of informationization on female entrepreneurship. McQuaid (2002) stresses that female entrepreneurship rate is low in the past due to institutional, capital, information, and time restrictions, but more and more new companies have been founded by women recently, which leads us to think about the role of informationization in this change. Informationization provides a channel for women to show their personality and talents and offer them entrepreneurship opportunities (Mathew, 2010; Prljić, Vučeković, \& Vujačić, 2015). Martin and Wright (2005) summarize three reasons why informationization is important for female entrepreneurship: Firstly, informationization carves out new areas that are more welcoming to women; secondly, in the context of information technology, women need less funds to start a business; and thirdly, informationization makes work more flexible, and women are able to strike a balance between family and career. Motilewa, Onakoya, and Oke (2015) based on Nigeria's case study show that information technology does have a positive influence in tackling the challenges faced by female entrepreneurs.

For both researches on information infrastructure, information technology usage, and entrepreneurship and those focusing on informationization and female entrepreneurship that exist in literature, scholars simply explore the influence of one aspect of informationization on entrepreneurship without examining the whole picture. Therefore, this paper will systematically study the impact of informationization on entrepreneurship.

\section{Method}

\section{Data}

Family plays an active role in enterprise formation and development in China (Pistrui, Huang, Oksoy, Jing, \& Welsch, 2010). Many businesses are family owned. Therefore, we explore the impact of informationization on entrepreneurship from the perspective of family entrepreneurship. The measure of family entrepreneurship and family characteristic variable is based on the "2011 China Household Finance Survey" conducted by Southwestern University of Finance and Economics. The main reason of choosing this data is that it contains a wealth of family entrepreneurial information, such as entrepreneurial choice, type, and income. It would provide a good sample for the research of this paper. In addition, the "2011 China Household Finance Survey" is used in some empirical literature (Chai, Chen, Huang, \& Ye, 2018; Zhang, Xu, Zhou, Zhang, \& Xie, 2014), indicating the research data is credible. The data covers 25 provinces and 8438 sample households. The survey mainly includes household demographics, assets and 
liabilities, insurance and security, spending, and income. Specifically, the "2011 China Household Finance Survey" surveys family entrepreneurial information in 2010.

Further, we need to measure the regional informationization level in order to discuss the research issue of this paper. The "2011 China Household Finance Survey" investigated the status of family entrepreneurship in a province. Therefore, we measure the regional informationization level from the provincial level. The data of provincial informationization is from the Report of China Informationization Development Assessment (2013). The report is released by the China Center for Information Industry Development, and it measures provincial informationization level in 2010, mainly from the aspects of information infrastructure and the extent and benefits of information and communication technology applications. This report draws on the indexes and experience of the international community informationization assessment while fully allowing for the national conditions of China. Thus, it could truly reflect the informationization level of the country.

In addition, the measure of provincial-level control variables is from China Statistics Yearbook in 2011. The 2011 China Statistics Yearbook actually reports the economic data in 2010.

Model

To find the relationship between informationization and entrepreneurship, the paper matches informationization at the provincial level with the household entrepreneurial data of each province. In this way, the problem studied in our paper becomes the influence of regional informationization level on family entrepreneurship in this region. In the study of Islam (2015), he adopted a probit model to discuss the relationship between regional government spending and individual entrepreneurial choice. Since Islam (2015) also studied the influence of regional factors on micro-individual entrepreneurship, this paper refers to his research to construct the econometric model shown below:

$$
\operatorname{Probit}\left(\operatorname{entrep}_{f p}=1\right)=F\left(\alpha+\beta \text { informationization }_{p}+\gamma F_{f p}+\phi P_{p}\right)
$$

where entrep $f p$ represents the entrepreneurial choice of family $f$ in province $p$ and informationization $_{p}$ represents the informationization level of province $p$. To attenuate the endogenous effect from missing important explanatory variables, the model incorporates two control variables: the characteristic variable at family level $\left(F_{f p}\right)$ and the characteristic variable at regional level $\left(P_{p}\right) . \beta$ is the core estimation coefficient of interest in this paper and is expected to be significantly positive.

The dependent variable is a dummy variable. If the ordinary least squares method is used to estimate Eq. (1), the result would be biased and deviating. Thus, the probit model is used instead. We can also use logit model to estimate Eq. (1), but there is no significant difference between the probit model and logit model. Therefore, this paper mainly adopts the probit model to study the effect of informationization on entrepreneurship and uses logit model for robustness test.

\section{Variables}

entrep is a dummy variable measuring whether a family is engaged in entrepreneurial activities. The "China Household Finance Survey" asks whether a family is engaged in 
industrial and commercial production and operation in 2010. For this question, a positive answer indicates that the family is entrepreneurial and entrep is assigned the value of 1 ; a negative answer indicates that the family is not entrepreneurial and entrep is 0 .

informationization is the natural logarithm of the informationization development index, which is used to measure the informationization level of each province. The informationization development index of each province comes from the Report of China Informationization Development Assessment (2013). The higher the informationization development index of a province is, the higher the informationization level it has.

$F$ is a family characteristic variable that affects family entrepreneurship. Referring to existing research (Aldrich \& Cliff, 2003; Paulson \& Townsend, 2004; Yueh, 2009), we add political network (PN), social network ( $\mathrm{SN}$ ), number of members (NM), risk aversion (RA), and house ownership (HO) to $F$. Political network is a dummy variable. If a family has at least one member as civil servant, the political network variable is valued 1 ; if none of the family members are civil servants, the value of this variable is zero. Compared with families that have none of their members as civil servants, those with members as civil servants have a more sophisticated political network. The social network is the natural logarithm of the amount of donation from a family to the Wenchuan earthquake-stricken area in 2008. There are two reasons for choosing the amount of donation as a measure of family's social network: For one thing, the amount of donation, to a certain extent, reflects the social status of the family, as the more it donates, the higher social status it enjoys and families with high social status usually have more extensive interpersonal networks. For the other, the Wenchuan earthquake is an exogenous shock, and this measure could be regarded as exogenous. The number of members is the number of family members. Risk aversion is divided into five levels. The higher the level, the more inclined for the family to avoid risks. House ownership is a dummy variable. If a family owns a house, this variable is valued 1; otherwise, it is valued zero.

According to existing research (Acs, Desai, \& Hessels, 2008; Ghani, Kerr, \& O'connell, 2014; Islam, 2015; Wennekers, Wennekers, Thurik, \& Reynolds, 2005), we add unemployment rate (UR), population density (PD), educational level (EL), economic development level (EDL), minimum wage standard (MWS), and proportion of fiscal revenue to GDP (FR). The unemployment rate is the urban registered unemployment rate. The population density is the natural logarithm of the ratio of the total population to the land area at the end of the year. The educational level is the natural logarithm of the number of graduates with a college degree or above per 100,000 people. The economic development level is measured by the per capita GDP and is the natural logarithm from empirical research. The minimum wage standard is the natural logarithm of the minimum wage based on the lowest standard. The proportion of fiscal revenue is the proportion of fiscal revenue to regional GDP.

\section{Descriptive analysis}

The Table 1 shows summary statistics of all variables based on variable measurement. The mean value of entrep is 0.1333 , which indicates that $13.33 \%$ of families choose to start a business in China. Prieger et al. (2016) argues that the optimal entrepreneurship 
Table 1 Summary statistics of all variables

\begin{tabular}{llllll}
\hline Variable & Variable definition & Mean & Std. dev. & Min & Max \\
\hline entrep & Family entrepreneurial choice & 0.1333 & 0.3400 & 0 & 1 \\
PN & Family political network & 0.0246 & 0.1549 & 0 & 1 \\
SN & Family social network & 3.9072 & 2.3885 & 0 & 13.2357 \\
NM & Number of family members & 3.4748 & 1.5474 & 1 & 18 \\
RA & Family risk aversion & 3.8470 & 1.2338 & 1 & 5 \\
HO & Family house ownership & 0.9081 & 0.2889 & 0 & 1 \\
informationization & Provincial informationization level & 3.9511 & 0.2674 & 3.5885 & 4.5078 \\
UR & Provincial unemployment rate & 0.0359 & 0.0063 & 0.0137 & 0.0435 \\
PD & Provincial population density & 5.6640 & 1.1685 & 2.0543 & 8.2039 \\
EL & Provincial education level & 9.1145 & 0.4128 & 8.5740 & 10.3577 \\
EDL & Provincial economic development level & 10.3200 & 0.4876 & 9.4818 & 11.2395 \\
MWS & Provincial minimum wage standard & 6.4721 & 0.1951 & 6.2146 & 7.0211 \\
FR & Provincial fiscal revenue & 0.0956 & 0.0282 & 0.0598 & 0.1674 \\
\hline
\end{tabular}

rate for middle-income countries is $25.1 \%$. Therefore, China's entrepreneurship rate still has a lot of room for improvement. Another variable we are concerned with is the provincial informationization level. In our research sample, the highest level of informationization is Shanghai, and the natural logarithm of the informationization development index is 4.5078; the lowest level of informationization is Gansu, and the natural logarithm of the informationization development index is 3.5885 . The maximum value is 1.26 times the minimum value. The data shows that there is obvious inter-provincial difference in the level of informationization (Additional file 1).

\section{Results and discussion}

\section{Basic regression results}

The dependent variable (entrep) is a dummy variable, and thus, this study uses the probit model to study the influence of informationization on entrepreneurship. In the probit model, the estimated coefficient could only reflect in what direction the explanatory variable influenced the dependent variable and could not reflect the magnitude of such influence. Therefore, the average marginal effect of the explanatory variable is calculated to reflect the influence of the explanatory variable on the dependent variable. In addition, this study adopts cross-section data which is usually vulnerable to heteroscedasticity. For this reason, robust standard error is used in the model estimation to reduce the impact of heteroscedasticity on the estimation result.

Column 1 of Table 2 reports the benchmark regression results of the influence of informationization on entrepreneurship. The estimated coefficient of informationization is positive at the significance level of $1 \%$, indicating that the higher the level of informatization, the higher the tendency of family entrepreneurship in the province. In terms of the magnitude of influence, when the informationization level increases by $1 \%$, the probability of the family choosing to start a business increases by 22.21 percentage points. This indicates that the role of informationization in promoting entrepreneurship is not only statistically significant, but also economically significant. The basic regression results show informationization plays a significant role in promoting 
Table 2 Regression results of the influence of informationization on entrepreneurship

\begin{tabular}{|c|c|c|c|c|c|}
\hline \multirow[t]{2}{*}{ Explanatory variable } & \multirow{2}{*}{$\begin{array}{l}\text { Basic regression } \\
\text { results } \\
1\end{array}$} & \multicolumn{4}{|c|}{ Robustness test } \\
\hline & & 2 & 3 & 4 & 5 \\
\hline Informationization & $0.2221^{* * *}(0.0666)$ & $\begin{array}{l}2.3873^{* *} \\
(1.0997)\end{array}$ & $\begin{array}{l}0.4838^{* * *} \\
(0.1097)\end{array}$ & $\begin{array}{l}0.2287^{* * *} \\
(0.0687)\end{array}$ & $\begin{array}{l}0.3040^{* * *} \\
(0.1005)\end{array}$ \\
\hline Political network & $\begin{array}{l}-0.0995^{* * *} \\
(0.0278)\end{array}$ & $\begin{array}{l}-0.1010^{* * *} \\
(0.0302)\end{array}$ & $\begin{array}{l}-0.0995^{* * *} \\
(0.0279)\end{array}$ & $\begin{array}{l}-0.1031^{* * *} \\
(0.0301)\end{array}$ & \\
\hline Social network & $0.0100^{* * *}(0.0018)$ & $\begin{array}{l}0.0103^{* * *} \\
(0.0019)\end{array}$ & $\begin{array}{l}0.0104^{* * *} \\
(0.0018)\end{array}$ & $\begin{array}{l}0.0106^{* * *} \\
(0.0018)\end{array}$ & $\begin{array}{l}0.0494^{* * *} \\
(0.0041)\end{array}$ \\
\hline Number of members & $0.0207^{* * *}(0.0024)$ & $\begin{array}{l}0.0203^{* * *} \\
(0.0028)\end{array}$ & $\begin{array}{l}0.0196^{* * *} \\
(0.0024)\end{array}$ & $\begin{array}{l}0.0199 * * * \\
(0.0023)\end{array}$ & $\begin{array}{l}0.0797^{* * *} \\
(0.0045)\end{array}$ \\
\hline Risk aversion & $\begin{array}{l}-0.0278^{* * *} \\
(0.0029)\end{array}$ & $\begin{array}{l}-0.0276^{* * *} \\
(0.0035)\end{array}$ & $\begin{array}{l}-0.0274^{* * *} \\
(0.0029)\end{array}$ & $\begin{array}{l}-0.0272^{* * *} \\
(0.0029)\end{array}$ & $\begin{array}{l}-0.1412^{* * *} \\
(0.0377)\end{array}$ \\
\hline House ownership & $-0.0167(0.0133)$ & $\begin{array}{l}-0.0011 \\
(0.0169)\end{array}$ & $\begin{array}{l}-0.0177 \\
(0.0133)\end{array}$ & $\begin{array}{l}-0.0179 \\
(0.0134)\end{array}$ & $\begin{array}{l}-0.1829 * * * \\
(0.0228)\end{array}$ \\
\hline Unemployment rate & $1.8725^{* * *}(0.7234)$ & $\begin{array}{l}8.0041^{* *} \\
(3.1978)\end{array}$ & $\begin{array}{l}2.3002^{* * *} \\
(0.7458)\end{array}$ & $\begin{array}{l}2.1579 * * * \\
(0.7676)\end{array}$ & $0.0166(0.0154)$ \\
\hline Population density & $-0.0045(0.0055)$ & $\begin{array}{l}-0.0423^{* *} \\
(0.0206)\end{array}$ & $0.0018(0.0054)$ & $\begin{array}{l}-0.0041 \\
(0.0054)\end{array}$ & $\begin{array}{l}-0.0069 \\
(0.0139)\end{array}$ \\
\hline Educational level & $-0.0496^{*}(0.0289)$ & $\begin{array}{l}0.4886^{*} \\
(0.2780)\end{array}$ & $\begin{array}{l}-0.1410^{* * *} \\
(0.0240)\end{array}$ & $\begin{array}{l}-0.0525^{*} \\
(0.0303)\end{array}$ & $\begin{array}{l}-0.1538^{* *} \\
(0.0698)\end{array}$ \\
\hline $\begin{array}{l}\text { Economic development } \\
\text { level }\end{array}$ & $-0.0129(0.0469)$ & $\begin{array}{l}-1.3055^{* *} \\
(0.6603)\end{array}$ & $0.0142(0.0335)$ & $\begin{array}{l}-0.0116 \\
(0.0490)\end{array}$ & $0.0291(0.0598)$ \\
\hline $\begin{array}{l}\text { Minimum wage } \\
\text { standard }\end{array}$ & $-0.0831^{*}(0.0439)$ & $\begin{array}{l}-0.1355^{* *} \\
(0.0545)\end{array}$ & $\begin{array}{l}-0.0700 \\
(0.0451)\end{array}$ & $\begin{array}{l}-0.0852^{*} \\
(0.0443)\end{array}$ & $0.0676(0.0455)$ \\
\hline $\begin{array}{l}\text { Proportion of fiscal } \\
\text { revenue }\end{array}$ & $\begin{array}{l}-0.8746^{* * *} \\
(0.2815)\end{array}$ & $\begin{array}{l}-5.9300^{* *} \\
(2.5418)\end{array}$ & $\begin{array}{l}-0.9978^{* * *} \\
(0.2692)\end{array}$ & $\begin{array}{l}-0.9010^{* * *} \\
(0.2943)\end{array}$ & $\begin{array}{l}-3.0486^{* * *} \\
(0.3535)\end{array}$ \\
\hline Pseudo goodness of fit & 0.0534 & & 0.0545 & 0.0530 & 0.0224 \\
\hline Wald exogenous test & & $4.1200^{* *}$ & & & \\
\hline Sample size & 8044 & 8044 & 8044 & 8044 & 41124 \\
\hline
\end{tabular}

"**" "***" and "***" represented significance levels of $10 \%, 5 \%$, and $1 \%$, respectively; the numbers in parentheses were robust standard errors of estimated coefficients; the reported estimated coefficients were average marginal effects

entrepreneurship, mainly because it can provide abundant opportunities and convenient conditions for entrepreneurship. According to the Report of China Informationization Development Assessment released by the China Center for Information Industry Development in 2015, 11 provinces have informationization development indexes higher than the national average, while the case is opposite for 20 provinces. In addition, this paper also calculates the entrepreneurship rate of each province according to the "China Household Finance Survey". The calculation results show that 8 provinces have entrepreneurship rates higher than the national average and the case is opposite for 17 provinces. This indicates that the informationization level and the entrepreneurship rate remain low in most parts of China. Under this context, it is of practical significance to the promotion of "mass entrepreneurship" and economic development if the government further strengthens informationization construction.

Next, we briefly explain the influence of control variables on entrepreneurship based on benchmark regression results. The estimated coefficient of the political network is negative at the significance level of $1 \%$, which indicates that families with political networks are 9.95 percentage points less likely to start a business than families without political networks. Necessity-push entrepreneurship is the main type of family entrepreneurship in China. With well-off conditions, families of civil servants are naturally 
less motivated to start a business. The social network has a positive estimated coefficient and passes the $1 \%$ significance test, indicating that an extensive social network plays a significant role in promoting entrepreneurship. This finding is consistent with the conclusions of Renzulli, Aldrich, and Moody (2000) and Yueh (2009). Entrepreneurship requires a range of resources such as information, capital, technology, and labor. People can get entrepreneurial resources they need through their social networks. Hence, residents with more extensive social networks are more likely to venture into entrepreneurial activities. The estimated coefficient of the number of members is positive at the significance level of $1 \%$. Families with more members are more likely to start a business. This is mainly because more family members mean wider social networks. The estimated coefficient of risk aversion is significantly negative, indicating that the higher the risk aversion, the lower the probability that families would choose to start a business. Empirical studies by Cramer, Hartog, Jonker, and Praag (2002) and Hvide and Panos (2014) also support this conclusion. The estimated coefficient of house ownership is negative, but it does not pass the significance test, which means that house ownership is not significantly related to the probability of starting a business.

In terms of regional characteristic variables, the estimated coefficient of unemployment rate is significantly positive. In areas with high unemployment rates, starting a business is a more likely choice for families, mainly because unemployment might force people to engage in entrepreneurial activities for their livelihood. The estimated coefficient of population density does not pass the significance test. Ghani et al. (2014) believe that areas with high population densities have more concentrated knowledge, resources, talents, and creativity, which could, in turn, stimulate people's enthusiasm for entrepreneurship. However, excessive concentration of population may generate congestion costs and thus increase the cost of entrepreneurship. Therefore, on the whole, population density does not have a significant impact on entrepreneurship. The estimated coefficient of educational level is significantly negative, indicating that families in areas with high educational attainment are less likely to start a business. An important reason is that people with higher educational degrees have more external choices and are more likely to get satisfactory jobs, and they are less motivated to engage in high-risk entrepreneurial activities (Van der Sluis, Van Praag, \& Vijverberg, 2008). The economic development level of a region does not have a significant impact on the choice of family entrepreneurship. The estimated coefficient of minimum wage standard is negative at the significance level of $10 \%$, indicating that this variable could inhibit entrepreneurship. Areas with high minimum wage standards also entail high opportunity cost and labor cost of entrepreneurial activities, so families are less likely to start a business. The estimated coefficient of fiscal revenue proportion is negative at the significant level of $1 \%$, and families in areas with high fiscal revenue proportion tend not to venture into entrepreneurship. The conclusion is consistent with the finding of Djankov, Ganser, McLiesh, Ramalho, and Shleifer (2010). A high proportion of fiscal revenue suggests a heavy tax burden on enterprises, which increases the cost of entrepreneurship and thus undermines the motivation to start a business. Therefore, it is important to reduce the burden on enterprises when the Chinese government tries to encourage residents into entrepreneurship. 


\section{Robustness test}

Benchmark regression results have proved the significant effect of informationization on entrepreneurship, yet this conclusion may still be affected by other factors, such as endogeneity, index metrics, econometric model, and research sample. In order to illustrate the robustness of the research conclusion, this paper also conducts a series of robustness tests.

\section{Regression on instrumental variable}

Endogeneity may lead to biased and inconsistent estimates. As far as this study is concerned, the endogeneity mainly comes from missing important explanatory variables and the possible bidirectional causality between informationization and entrepreneurship. To solve the endogenous problem, we have to find an appropriate instrumental variable. With reference to the research of Kolko (2012), this paper uses altitude as an instrumental variable of informationization. The geographical environment of a region can affect the cost of local informationization construction. Altitude is an important geographical factor that affects informationization construction. Areas with higher altitudes need higher costs of informationization construction and have lower informationization levels. In addition, as an exogenous geographical factor, altitude is not affected by family entrepreneurship. Arguably, altitude is an effective instrumental variable of informationization. With regard to the measurement of altitude for each province, this paper considers the average altitude of major cities in each province to approximate the altitude of each province.

Based on the selected instrumental variable for informationization, this paper reestimates Eq. (1) using the IV probit model. The estimation results are shown in column 2 of Table 2. The estimated coefficient of informationization is positive and passes the $1 \%$ significance test. In addition, the Wald exogenous test passes the $5 \%$ significance test, which indicates that the test rejects the null hypothesis that the informationization variable is exogenous, suggesting that the regression using the IV probit model is effective in this paper. The regression results show that the research conclusion that informationization promotes entrepreneurship after considering the endogenous problem is robust.

\section{Remeasurement of informationization variable}

The informationization evaluation results vary with evaluation indexes and methods. Therefore, in order to prove that the research conclusion does not vary with informationization measurement methods, this paper uses the informationization development indexes constructed by the National Bureau of Statistics to reevaluate the influence of informationization on entrepreneurship.

The informationization development indexes constructed by the National Bureau of Statistics are used to comprehensively measure the informationization levels of various provinces in China from the aspects of informationization infrastructure construction, information industry and technology, informationization consumption level, environmental constraints, and development effects. The National Bureau of Statistics and the China Center for Information Industry Development offer different informationization measurement indexes and methods. Since we need to further study the influence of 
informationization infrastructure, government informationization, resident informationization, and enterprise informationization on entrepreneurship, the index system provided by the China Center for Information Industry Development better suits our research requirement. Thus, this paper adopts the informationization development indexes provided by the China Center for Information Industry Development for empirical research and those from the National Bureau of Statistics for robustness test. The data of the latter is derived from the 2012 Annual Report of China Informationization Development Index Statistical Monitoring. In addition, the correlation between the two groups of informationization development indexes provided by the two institutions is calculated in this paper. The calculation results show that the correlation is as high as 0.93 and passes the $1 \%$ significance test, which means that both of the index systems could consistently reflect the informationization level of each province.

Column 3 of Table 2 reports the regression results of the informationization indexes remeasured. The regression results show that the estimated coefficient of informationization is positive at the significance level of $1 \%$, which indicates that the conclusion that informationization greatly promotes entrepreneurship is still well grounded even if the evaluation indexes and methods are changed.

\section{Logit model}

Although there is no essential difference between the estimation results based on the probit model and the logit model, we would also adopt the logit model to estimate the impact of informationization on entrepreneurship in order to show that the conclusion of the paper is not changed due to the change of the measurement model. Column 4 of Table 2 illustrates the regression results based on the logit model. The estimated coefficient of informationization is significantly positive. As we saw in columns 1 and 4, the estimated coefficients of informationization based on the probit model and the logit model are very similar. Therefore, we believe that the research conclusion that regional informationization has a promotion effect on entrepreneurship would not change whether using the probit model or the logit model.

\section{Research sample replacement}

There are two main surveys to investigate the entrepreneurship of Chinese families, namely China Household Finance Survey and China Family Panel Studies. In comparison, China Household Finance Survey includes more entrepreneurial information, such as entrepreneurial industries, entrepreneurial types, and number of employees employed. This information is conductive to study the heterogeneous influences of informationization on entrepreneurship and influence of informationization on entrepreneurial performance. Therefore, this paper eventually chooses the China Household Finance Survey to analyze the effect of informationization on entrepreneurship. However, China Household Finance Survey only supplies cross-section data in 2010, which may lead to inaccurate estimation results due to the missing time factor. Fortunately, China Family Panel Studies provide family entrepreneurship information for 2011, 2013, and 2015. Hence, we use this dataset for robustness test.

Due to the replacement of research sample, we need to redefine some control variables in family level, but the definition of control variables in the provincial level has 
not changed. The social network is the natural logarithm of the amount of family donations per year. Risk aversion is the dummy variable. If a family purchases a financial product, this variable is valued 0 ; otherwise, it is valued 1. Column 5 of Table 2 shows the regression results based on China Family Panel Studies. China Family Panel Studies do not provide any information regarding the political network of family. Therefore, column 5 does not include the political network variable. The estimated coefficient of informationization is significantly positive, which indicates that the research conclusion is still true when we expand the study sample and consider the time factor.

\section{Influences of different dimensions of informationization on entrepreneurship}

Informationization is strongly penetrable, and it can be applied deeply into all aspects of economy and society. It is mainly divided into informationization applications in the government, residents, and enterprises. Informationization applications are realized on the basis of information infrastructure. Therefore, informationization can be roughly decomposed into information infrastructure, government informationization, resident informationization, and enterprise informationization. These different dimensions have different influences on entrepreneurship, and this is the topic of further interest in this paper. In order to study this issue, this paper measures the information infrastructure construction level, government informationization degree, resident informationization degree, and enterprise informationization degree of each province from the network readiness index, the government application index, the resident application index, and the enterprise application index given in the Report of China Informationization Development Assessment (2013). In the empirical research, the four indexes above takes on the form of natural logarithm.

Table 3 reports the regression results of the influences of different informationization dimensions on entrepreneurship. Column 1 shows the influence of information infrastructure on entrepreneurship. Its estimated coefficient is positive at the significance level of $1 \%$, indicating that the more developed the information infrastructure in a region, the more likely the families there would choose to start a business. Specifically, every $1 \%$ increase in the information infrastructure level in a region would lead to an increase in the probability of family entrepreneurship by 13.8 percentage points. Information infrastructure not only spurs significant entrepreneurial opportunities, but also enhances connectivity and interaction between people, facilitates exchange and sharing of knowledge and ideas, and thus promotes entrepreneurship (Audretsch et al., 2015).

Column 2 shows the regression results of government informationization and family entrepreneurial choice. The estimated coefficient of government informationization is positive and passes the $1 \%$ significance test. Every $1 \%$ increase in government informationization would lead to an increase in the probability of family entrepreneurship by 3.71 percentage points. Das and Das (2015) also agree that government informationization can promote market entry for enterprises. Government informationization promotes entrepreneurship mainly from three aspects. Firstly, it helps promote inter-departmental cooperation, breaks information islands, and realizes information transfer and resources scheduling between departments, thus helping to optimize administrative approval processes and improve administrative approval efficiency, which can better motivate residents to start a business. Secondly, government information disclosure made possible by 
Table 3 Regression results of different dimensions of informationization on entrepreneurship

\begin{tabular}{|c|c|c|c|c|}
\hline Explanatory variable & 1 & 2 & 3 & 4 \\
\hline Information infrastructure & $0.1380^{* * *}(0.0296)$ & & & \\
\hline $\begin{array}{l}\text { Government } \\
\text { informationization }\end{array}$ & & $0.0371^{* * *}(0.0134)$ & & \\
\hline Resident informationization & & & $0.0646^{*}(0.0379)$ & \\
\hline Enterprise informationization & & & & $\begin{array}{l}-0.0989^{* * *} \\
(0.0255)\end{array}$ \\
\hline Political network & $\begin{array}{l}-0.0985^{* * *} \\
(0.0279)\end{array}$ & $\begin{array}{l}-0.0998^{* * *} \\
(0.0278)\end{array}$ & $\begin{array}{l}-0.0998^{* * *} \\
(0.0278)\end{array}$ & $\begin{array}{l}-0.0976^{* * *} \\
(0.0278)\end{array}$ \\
\hline Social network & $0.0101^{* * *}(0.0018)$ & $0.0101^{* * *}(0.0018)$ & $0.0101^{* * *}(0.0018)$ & $0.0103^{* * *}(0.0018)$ \\
\hline Number of members & $0.0210^{* * *}(0.0024)$ & $0.0203^{* * *}(0.0024)$ & $0.0206^{* * *}(0.0024)$ & $0.0206^{* * *}(0.0024)$ \\
\hline Risk aversion & $\begin{array}{l}-0.0280^{* * *} \\
(0.0029)\end{array}$ & $\begin{array}{l}-0.0278^{* * *} \\
(0.0029)\end{array}$ & $\begin{array}{l}-0.0279^{* * *} \\
(0.0029)\end{array}$ & $\begin{array}{l}-0.0281^{* * *} \\
(0.0029)\end{array}$ \\
\hline House ownership & $-0.0202(0.0133)$ & $-0.0166(0.0133)$ & $-0.0176(0.0133)$ & $-0.0193(0.0133)$ \\
\hline Unemployment rate & $0.8237(0.7292)$ & $1.0720(0.7202)$ & $2.0797^{* *}(0.8422)$ & $1.1790(0.7368)$ \\
\hline Population density & $0.0074(0.0057)$ & $-0.0022(0.0053)$ & $-0.0050(0.0057)$ & $0.0100(0.0063)$ \\
\hline Educational level & $-0.0400(0.0275)$ & $\begin{array}{l}-0.1043^{* * *} \\
(0.0229)\end{array}$ & $\begin{array}{l}-0.0908^{* * *} \\
(0.0260)\end{array}$ & $\begin{array}{l}-0.1022^{* * *} \\
(0.0236)\end{array}$ \\
\hline Economic development level & $-0.0102(0.0358)$ & $0.1071^{* * *}(0.0233)$ & $0.1158^{* * *}(0.0231)$ & $0.1575^{* * *}(0.0233)$ \\
\hline Minimum wage standard & $-0.0876^{* *}(0.0429)$ & $-0.0675(0.0453)$ & $-0.1247^{* *}(0.0511)$ & $\begin{array}{l}-0.1370^{* * *} \\
(0.0451)\end{array}$ \\
\hline Proportion of fiscal revenue & $\begin{array}{l}-0.6485^{* * *} \\
(0.2256)\end{array}$ & $-0.4556^{* *}(0.2221)$ & $-0.6588^{* *}(0.2904)$ & $-0.5609^{* *}(0.2255)$ \\
\hline Pseudo goodness of fit & 0.0548 & 0.0529 & 0.0522 & 0.0541 \\
\hline Sample size & 8044 & 8044 & 8044 & 8044 \\
\hline
\end{tabular}

"**," "**," and " "***" represented significance levels of $10 \%, 5 \%$, and $1 \%$, respectively; the numbers in parentheses were robust standard errors of estimated coefficients; the reported estimated coefficients were average marginal effects

government informationization can effectively restrain the government's control of the market economy, make the exercise of power more transparent, reduce the cost of rentseeking, and create transparent business environment for entrepreneurship. Thirdly, government informationization can promote innovative supply of public services and integration of service resources, result in an integrated online public service system, provide a full range of entrepreneurial services, and reduce the cost of entrepreneurship.

Column 3 explores the influence of resident informationization on entrepreneurship. The estimated coefficient of resident informationization is positive, but it is less statistically significant than the estimated coefficients of informationization infrastructure and government informationization, and it only passes the 10\% significance test. Every $1 \%$ increase in resident informationization would result in an increase in the probability of family entrepreneurship by 6.46 percentage points. Resident informationization has a positive influence on entrepreneurship for at least three reasons. Firstly, it helps residents access the global network; in other words, residents can expand the market scope and seek opportunities for entrepreneurship (McQuaid, 2002). Secondly, entrepreneurial activities usually involve collecting and processing a large amount of information. Resident informationization is conducive to this task and thus encourages residents to engage in entrepreneurial activities. Thirdly, the high requirements for capital, system, and information in traditional industries make them prohibitive to entrepreneurs, while the development of e-commerce and the improvement in resident informationization 
help residents to engage in entrepreneurial activities in the field of e-commerce with less capital and more flexible time.

Column 4 shows the regression results of the influence of enterprise informationization on entrepreneurship. Its estimated coefficient is negative at the significance level of $1 \%$. Every $1 \%$ increase in enterprise informationization would lead to a decrease in the probability of family entrepreneurship by 9.89 percentage points. Arguably, different from the influences of informationization infrastructure, government informationization, and resident informationization on entrepreneurship, enterprise informationization exerts a negative influence. Higher enterprise informationization in a region means that local enterprises are more competitive in the market, which undoubtedly increases the threshold for market access. To compete with incumbent enterprises, interested entrants need to invest more in information. This increases the cost of entrepreneurship for residents and discourages some otherwise entrepreneurial residents from the market. There is a dilemma here: improving the informationization of enterprises can enhance their competitiveness, while it hinders entrepreneurship. In this case, the government should build an informationization service platform for new ventures in order to reduce the informationization investment needed by resident entrepreneurs in the startup stage.

\section{Heterogeneous influences of informationization on entrepreneurship}

In the previous part of this study, entrepreneurial activities are considered homogeneous. In fact, this is not the case. In general, entrepreneurship can be broadly divided into corporate entrepreneurship and self-employed entrepreneurship. Compared with the latter, corporate entrepreneurship has to overcome higher thresholds of capital, technology, and management and delivers greater economic and social benefits. The influences of the same factor vary with different types of entrepreneurship. In addition, different industries have different informationization levels, which, in turn, have different influences on business ventures in different industries. Based on the analysis above, this section focuses on the heterogeneous influences of informationization on different types of entrepreneurship and different entrepreneurial industries.

\section{Heterogeneity of entrepreneurial types}

In order to explore the influence of informationization on different types of entrepreneurship, the dependent variable (entrep) needs to be redefined. If a family is not engaged in entrepreneurial activities, entrep is assigned with a value of 0 . If the business is started in the form of enterprise, entrep is valued 1. If the business is on selfemployed basis, entrep is valued 2. The "China Household Finance Survey" divides family entrepreneurship into joint stock company, limited liability company, partnership, sole proprietorship, self-employed individual/privately, or individually owned business. In this paper, joint stock company, limited liability company, partnership, and sole proprietorship are classified as corporate entrepreneurship. According to statistics, of 1125 entrepreneurial families, $13.78 \%$ chose corporate entrepreneurship and $86.22 \%$ chose self-employed entrepreneurship. Individually owned business is the main type of entrepreneurship for Chinese residents, which is also evidenced for the prevailing necessity-push entrepreneurship among Chinese residents. 
Since the dependent variable here is a multiple-choice variable, this paper borrows the multiple-choice probit model to study the influence of informationization on different types of entrepreneurship. In the multiple-choice probit model, the baseline group is families that are not entrepreneurial, and all the estimated coefficients are compared with the results of the baseline group. Columns 1 and 2 of Table 4 reports the estimates. Column 1 shows the regression results of informationization and corporate entrepreneurship. The estimated coefficient of informationization is positive, but it does not pass the significance test. Every $1 \%$ increase in the informationization level of the region would result in an increase in the probability of family corporate entrepreneurship by 4.02 percentage points. Column 2 shows the regression results of informationization and self-employed entrepreneurship. The estimated coefficient of informationization is positive and passes the $1 \%$ significance test. Every $1 \%$ increase in the informationization level would result in an increase in the probability of family self-employed entrepreneurship by 17.43 percentage points. In contrast, informationization plays a bigger role in promoting self-employed entrepreneurship. The main reason is that informationization provides flexible and convenient conditions for entrepreneurship, which is in line with flexible self-employment entrepreneurship. Thus, informationization promotes selfemployment entrepreneurship better.

Table 4 Regression results of the heterogeneous influences of informationization on entrepreneurship

\begin{tabular}{|c|c|c|c|c|c|}
\hline Explanatory variable & (1) Enterprise & $\begin{array}{l}\text { (2) Self-employed } \\
\text { entrepreneurs }\end{array}$ & $\begin{array}{l}\text { (3) Secondary } \\
\text { industries }\end{array}$ & $\begin{array}{l}\text { (4) Domestic } \\
\text { services }\end{array}$ & $\begin{array}{l}\text { (5) Productive } \\
\text { services }\end{array}$ \\
\hline Informationization & $\begin{array}{l}0.0402 \\
(0.0275)\end{array}$ & $0.1743^{* * *}(0.0629)$ & $\begin{array}{l}0.1166^{* * *} \\
(0.0375)\end{array}$ & $\begin{array}{l}0.0776 \\
(0.0556)\end{array}$ & $0.0235(0.0247)$ \\
\hline Political network & $\begin{array}{l}-0.0002 \\
(0.0076)\end{array}$ & $-0.1150^{* * *}(0.0299)$ & $\begin{array}{l}-0.0184 \\
(0.0131)\end{array}$ & $\begin{array}{l}-0.0673^{* * *} \\
(0.0248)\end{array}$ & $\begin{array}{l}-0.0089 \\
(0.0088)\end{array}$ \\
\hline Social network & $\begin{array}{l}0.0062^{* * *} \\
(0.0011)\end{array}$ & $0.0044^{* * *}(0.0016)$ & $\begin{array}{l}0.0021^{* *} \\
(0.0009)\end{array}$ & $\begin{array}{l}0.0054^{* * *} \\
(0.0015)\end{array}$ & $\begin{array}{l}0.0025^{* * *} \\
(0.0007)\end{array}$ \\
\hline $\begin{array}{l}\text { Number of } \\
\text { members }\end{array}$ & $\begin{array}{l}0.0026^{* * *} \\
(0.0010)\end{array}$ & $0.0186^{* * *}(0.0022)$ & $\begin{array}{l}0.0042^{* * *} \\
(0.0010)\end{array}$ & $\begin{array}{l}0.0154^{* * *} \\
(0.0020)\end{array}$ & $0.0012(0.0007)$ \\
\hline Risk aversion & $\begin{array}{l}-0.0074^{* * *} \\
(0.0012)\end{array}$ & $-0.0200^{* * *}(0.0028)$ & $\begin{array}{l}-0.0058^{* * *} \\
(0.0013)\end{array}$ & $\begin{array}{l}-0.0177^{* * *} \\
(0.0025)\end{array}$ & $\begin{array}{l}-0.0025^{* *} \\
(0.0010)\end{array}$ \\
\hline House ownership & $\begin{array}{l}-0.0068 \\
(0.0050)\end{array}$ & $-0.0102(0.0126)$ & $\begin{array}{l}0.0175^{* *} \\
(0.0079)\end{array}$ & $\begin{array}{l}-0.0327^{* * *} \\
(0.0110)\end{array}$ & $\begin{array}{l}-0.0005 \\
(0.0045)\end{array}$ \\
\hline Unemployment rate & $\begin{array}{l}-0.6495^{* *} \\
(0.2623)\end{array}$ & $2.9215^{* * *}(0.7182)$ & $0.3678(0.3602)$ & $\begin{array}{l}1.5463^{* *} \\
(0.6286)\end{array}$ & $0.3606(0.2864)$ \\
\hline Population density & $\begin{array}{l}0.0031 \\
(0.0025)\end{array}$ & $-0.0073(0.0052)$ & $0.0048(0.0032)$ & $\begin{array}{l}-0.0049 \\
(0.0046)\end{array}$ & $\begin{array}{l}-0.0001 \\
(0.0018)\end{array}$ \\
\hline Educational level & $\begin{array}{l}-0.0086 \\
(0.0109)\end{array}$ & $-0.0523^{*}(0.0281)$ & $\begin{array}{l}-0.0136 \\
(0.0155)\end{array}$ & $\begin{array}{l}-0.0266 \\
(0.0246)\end{array}$ & $\begin{array}{l}-0.0056 \\
(0.0118)\end{array}$ \\
\hline $\begin{array}{l}\text { Economic } \\
\text { development level }\end{array}$ & $\begin{array}{l}-0.0196 \\
(0.0200)\end{array}$ & $0.0170(0.0447)$ & $\begin{array}{l}-0.0385 \\
(0.0273)\end{array}$ & $\begin{array}{l}0.0246 \\
(0.0390)\end{array}$ & $0.0066(0.0187)$ \\
\hline $\begin{array}{l}\text { Minimum wage } \\
\text { standard }\end{array}$ & $\begin{array}{l}0.0040 \\
(0.0178)\end{array}$ & $-0.0853^{* *}(0.0416)$ & $0.0003(0.0205)$ & $\begin{array}{l}-0.0968^{* * *} \\
(0.0375)\end{array}$ & $\begin{array}{l}-0.0027 \\
(0.0139)\end{array}$ \\
\hline $\begin{array}{l}\text { Proportion of fiscal } \\
\text { revenue }\end{array}$ & $\begin{array}{l}-0.1097 \\
(0.1178)\end{array}$ & $-0.7392^{* * *}(0.2643)$ & $\begin{array}{l}-0.2452 \\
(0.1541)\end{array}$ & $\begin{array}{l}-0.3489 \\
(0.2350)\end{array}$ & $\begin{array}{l}-0.2489^{* *} \\
(0.1169)\end{array}$ \\
\hline Sample size & 8044 & & 7980 & & \\
\hline
\end{tabular}

"“*," "**," and "****" represented significance levels of $10 \%, 5 \%$, and $1 \%$, respectively; the numbers in parentheses were robust standard errors of estimated coefficients; the reported estimated coefficients were average marginal effects 


\section{Heterogeneity of entrepreneurial industries}

In order to study the industry heterogeneity in the influence of informationization on entrepreneurship, this paper divides industry into secondary industries, domestic services, and productive services, ${ }^{2}$ and the dependent variable (entrep) is redefined. If a family is not engaged in entrepreneurial activities, entrep is assigned with a value of 0 . If it is engaged in a secondary industry, entrep is valued 1. If it is engaged in a domestic service, entrep is valued 2. If it is engaged in a productive service, entrep is valued 3. According to statistics, $18.68 \%$ of entrepreneurial families start businesses in secondary industries, $71.61 \%$ in domestic services, and $9.71 \%$ in productive services. Most Chinese residents choose to start a business in domestic services, mainly because of these industries pose low barriers to entrepreneurship and provide flexible entrepreneurial forms.

As with the study on the heterogeneity of entrepreneurship types, the multiplechoice probit model is used to study the influence of informationization on entrepreneurship in different industries. Column 3-5 of Table 4 reports the estimates. Column 3 explores the influence of informationization on family entrepreneurship in secondary industries. The estimated coefficient of informationization is positive and passes the $1 \%$ significance test. Every 1\% increase in the informationization level of a region would result in an increase in the probability of families choosing to start businesses in secondary industries by 11.66 percentage points. Column 4 reports the regression results of informationization and entrepreneurship in domestic service industries. The estimated coefficient of informationization is positive, but it does not pass the significance test. Every $1 \%$ increase in the informationization level would result in the probability of families choosing to start businesses in domestic service industries by 7.76 percentage points. Column 5 lists the regression results of the influence of informationization on family entrepreneurship in productive service industries. The estimated coefficient of informationization is positive, but it does not pass the significance test. Every 1\% increase in the informationization level of a region would result in an increase in the probability of families choosing to start businesses in productive service industries by 2.35 percentage points. The estimation results in column 3-5 shows that informationization plays a greater and more significant role in promoting family entrepreneurship in secondary industries. Secondary industries are more informationalized, and the improved informationization level of a region can significantly increase the informationization level of secondary industries and thus promote the level of entrepreneurship in secondary industries. However, productive service industries are similarly informationalized. Why does informationization not significantly promote the entrepreneurial level in these industries? An important reason can be attributed to the strict regulations in productive service industries that disqualify a large number of entrepreneurial residents from venturing into these industries. Even if informationization creates opportunities and conditions for entrepreneurship, most residents are still not able to start their businesses in these industries. Therefore, informationization does not play a significant role

\footnotetext{
${ }^{2}$ Secondary industries include mining, manufacturing, electricity, gas, water production and supply, and construction. Domestic services include wholesale and retail, accommodation and catering, real estate, water conservancy, environmental and public facilities management, residential services, education, health, social security and social welfare, culture, sports and entertainment, public administration, and social organizations. Productive services include transportation, warehousing and postal services, information transmission, computer services and software, finance, leasing and business services, scientific research, technical services, and geological surveys.
} 
in improving the entrepreneurial level in productive service industries. The government should lift unnecessary regulations in these industries to fully exploit the role of informationization in promoting entrepreneurship and fuel the development of productive service industries.

\section{Influence of informationization on entrepreneurial performance}

From the perspective of the life cycle of entrepreneurship, entrepreneurship includes not only the establishment of a new organization, i.e., entrepreneurial choice, but also the development of the new organization, i.e., entrepreneurial performance. The previous part of research focuses on the influence of informationization on entrepreneurial choice and finds that informationization can significantly increase the probability of residents to start a business. What is the influence of informationization on entrepreneurial performance? This is the main research issue in this section. Entrepreneurship not only addresses the income of entrepreneurs, but also solves the social employment. Therefore, entrepreneurship has two basic effects: income effect and employment effect. Income and employment are important indicators to measure entrepreneurial performance. The foothold of this section is to study whether informationization can help realize the income effect and the employment effect of entrepreneurship.

This section focuses on the income and employment effects of entrepreneurial families. However, if this study covers only entrepreneurial families and excludes families not engaged in entrepreneurial ventures, it would produce self-selected samples rather than random samples (Heckman, 1979). If the self-selected samples are estimated by ordinary least squares, the results might be biased and inconsistent (Heckman, 1979). To overcome the sample selection bias, the Heckman two-stage model is used to study the influence of informationization on entrepreneurial performance. In the study of Magri (2011), he also used the Heckman two-stage model to analyze the effect of initial net wealth of household on the size of entrepreneurship. Therefore, it is suitable for studying the relationship between informationization and entrepreneurial performance using the Heckman two-stage model. The Heckman two-stage model is described briefly as follows.

The Heckman model for the first stage is the entrepreneurial choice model shown in Eq. (1). The Heckman two-stage model requires that the first-stage model should include at least one exclusive explanatory variable. This explanatory variable influences the entrepreneurial choice of a family but not the entrepreneurial performance in the second-stage model. Thus, in this section, the average age of family members and its square are added to the family characteristic variable $(F)$ in Eq. (1). The average age of family members has a direct impact on family entrepreneurial choice, and there is a non-linear relationship between age and entrepreneurial choice. In addition, when regressing entrepreneurial performance based on the average age of family members and its square in Eq. (2), we find that the average age of family members and its square have no significant effect on entrepreneurial performance. It could be concluded that the average age of family members and its square are suitable exclusive explanatory variables.

The Heckman model for the second stage is a linear equation that studies the influence of informationization on entrepreneurial performance, as shown in Eq. (2): 


$$
\text { performance }_{f p}=\alpha+\beta \text { information }_{p}+\gamma F_{f p}+\phi P_{p}+\phi \lambda_{f p}+\mu_{f p}
$$

where performance ${ }_{f p}$ represents the entrepreneurial performance of family $f$ in province $p$. We measure entrepreneurial performance by entrepreneurial income and the number of employees in the new business and take their natural logarithms in empirical research. Since both of the measures are zero for some families, no natural logarithms could be taken. In this case, the entrepreneurial incomes and the number of employees plus 1 is the solution, and then, natural logarithms are taken, for all families. $F_{f p}, P_{p}$, and $\mu_{f p}$ represent family characteristic variable, regional characteristic variable, and random error term, respectively. Once again, $F$ in Eq. (2) excludes the average age of family members and its square, which are instead included in Eq. (1). $\lambda_{f p}$ represents the inverse Mills ratio to overcome the selection bias of the studied samples. We first get the inverse Mills ratio from regression in the first stage, and then add this inverse Mills ratio to the entrepreneurial performance model in the second stage. If the inverse Mills ratio is significantly non-zero, a sample selection bias is strongly suggested and the use of the Heckman two-stage model turns out to be valid; if it is significantly zero, it means that the Heckman two-stage model is unnecessary. The inverse Mills ratio is calculated as shown in Eq. (3) (Heckman, 1979):

$$
\lambda_{f p}=\frac{f\left(\alpha+\text { Binformation }_{p}+\gamma F_{f p}+\phi P_{p}\right)}{F\left(\alpha+\text { Binformation }_{p}+\gamma F_{f p}+\phi P_{p}\right)}
$$

where $f(\cdot)$ and $F(\cdot)$ represents the probability density function and the probability distribution function of standard normal distribution, respectively.

Table 5 shows the influence of informationization on entrepreneurial performance. Columns 1 and 2 report the influence of informationization on entrepreneurial income based on the Heckman two-stage model. Column 1 is the entrepreneurial choice model for the first stage, and column 2 is the entrepreneurial income model for the second stage. In column 1, the estimated coefficient of informationization is significantly positive, which indicates that informationization has a significant effect on entrepreneurial promotion. In column 2, the estimated coefficient of informationization is positive at the significance level of $5 \%$. Every $1 \%$ increase in the informationization level of a region would result in an increase in the entrepreneurial income of a family by $3.86 \%$. The inverse Mills ratio does not pass the significance test, which means that it is unnecessary to apply the Heckman two-stage model in studying the influence of informationization on entrepreneurial income, which is thus remeasured by using the ordinary least squares method. The regression results are shown in column 3. In column 3, the estimated coefficient of informationization is positive at the significance level of $5 \%$. Every $1 \%$ increase in the informationization level of a region would result in an increase in the entrepreneurial income of a family by $4.03 \%$. Clearly, both the results from the Heckman two-stage model and the ordinary least squares method prove that informationization could help realize the income effect of entrepreneurship.

Columns 4 and 5 of Table 5 report the regression results of informationization and entrepreneurial employment effect based on the Heckman two-stage model. Column 4 is the entrepreneurial choice model for the first stage, and column 5 is the entrepreneurial employment effect model for the second stage. As shown in column 5, the estimated coefficient of informationization is positive at the $10 \%$ significance level, 
Table 5 Regression results of the influence of informationization on entrepreneurial performance

\begin{tabular}{|c|c|c|c|c|c|c|}
\hline $\begin{array}{l}\text { Explanatory } \\
\text { variable }\end{array}$ & $\begin{array}{l}\text { (1) } \\
\text { Entrepreneurial } \\
\text { choice }\end{array}$ & $\begin{array}{l}\text { (2) Income } \\
\text { effect }\end{array}$ & $\begin{array}{l}\text { (3) Income } \\
\text { effect }\end{array}$ & $\begin{array}{l}\text { (4) } \\
\text { Entrepreneurial } \\
\text { choice }\end{array}$ & $\begin{array}{l}\text { (5) } \\
\text { Employment } \\
\text { effect }\end{array}$ & $\begin{array}{l}\text { (6) } \\
\text { Employment } \\
\text { effect }\end{array}$ \\
\hline Informationization & $\begin{array}{l}0.9483^{* * *} \\
(0.3144)\end{array}$ & $\begin{array}{l}3.8555^{* *} \\
(1.8589)\end{array}$ & $\begin{array}{l}4.0260^{* *} \\
(1.9471)\end{array}$ & $\begin{array}{l}1.0327^{* * *} \\
(0.3631)\end{array}$ & $\begin{array}{l}0.9521^{*} \\
(0.5780)\end{array}$ & $\begin{array}{l}1.4647^{* * *} \\
(0.5029)\end{array}$ \\
\hline Political network & $\begin{array}{l}-0.5193^{* * *} \\
(0.1757)\end{array}$ & $\begin{array}{l}0.2476 \\
(0.9029)\end{array}$ & $\begin{array}{l}0.1387 \\
(0.9277)\end{array}$ & $\begin{array}{l}-0.4773^{* * *} \\
(0.1397)\end{array}$ & $\begin{array}{l}0.7683 \\
(0.4688)\end{array}$ & $\begin{array}{l}0.5013 \\
(0.3523)\end{array}$ \\
\hline Social network & $\begin{array}{l}0.0377^{* * *} \\
(0.0100)\end{array}$ & $\begin{array}{l}0.1707^{* * *} \\
(0.0661)\end{array}$ & $\begin{array}{l}0.1783^{* * *} \\
(0.0489)\end{array}$ & $\begin{array}{l}0.0366^{* * *} \\
(0.0107)\end{array}$ & $\begin{array}{l}0.1070^{* * *} \\
(0.0239)\end{array}$ & $\begin{array}{l}0.1282^{* * *} \\
(0.0188)\end{array}$ \\
\hline $\begin{array}{l}\text { Number of } \\
\text { members }\end{array}$ & $\begin{array}{l}0.0589^{* * *} \\
(0.0110)\end{array}$ & $\begin{array}{l}0.0649 \\
(0.0934)\end{array}$ & $\begin{array}{l}0.0779 \\
(0.0643)\end{array}$ & $\begin{array}{l}0.0591 * * * \\
(0.0120)\end{array}$ & $\begin{array}{l}-0.0738^{* * *} \\
(0.0280)\end{array}$ & $\begin{array}{l}-0.0367^{*} \\
(0.0203)\end{array}$ \\
\hline Risk aversion & $\begin{array}{l}-0.1054^{* * *} \\
(0.0167)\end{array}$ & $\begin{array}{l}0.0447 \\
(0.1318)\end{array}$ & $\begin{array}{l}0.0237 \\
(0.0852)\end{array}$ & $\begin{array}{l}-0.1031^{* * *} \\
(0.0167)\end{array}$ & $\begin{array}{l}-0.0332 \\
(0.0331)\end{array}$ & $\begin{array}{l}-0.0910^{* * *} \\
(0.0267)\end{array}$ \\
\hline House ownership & $\begin{array}{l}-0.0440 \\
(0.0600)\end{array}$ & $\begin{array}{l}0.5175 \\
(0.4571)\end{array}$ & $\begin{array}{l}0.5034 \\
(0.3895)\end{array}$ & $\begin{array}{l}-0.0124 \\
(0.0660)\end{array}$ & $\begin{array}{l}0.3045^{* * *} \\
(0.0979)\end{array}$ & $\begin{array}{l}0.2751^{* * *} \\
(0.0783)\end{array}$ \\
\hline Average age & $\begin{array}{l}2.1919^{* *} \\
(0.8576)\end{array}$ & & & $\begin{array}{l}2.6539^{* * *} \\
(1.0216)\end{array}$ & & \\
\hline $\begin{array}{l}\text { Average age } \\
\text { squared }\end{array}$ & $\begin{array}{l}-0.3769^{* * *} \\
(0.1191)\end{array}$ & & & $\begin{array}{l}-0.4421^{* * *} \\
(0.1419)\end{array}$ & & \\
\hline $\begin{array}{l}\text { Unemployment } \\
\text { rate }\end{array}$ & $\begin{array}{l}16.0362^{* * *} \\
(3.5687)\end{array}$ & $\begin{array}{l}-11.1587 \\
(21.6587)\end{array}$ & $\begin{array}{l}-8.4651 \\
(17.8867)\end{array}$ & $\begin{array}{l}10.1414^{* * *} \\
(3.8959)\end{array}$ & $\begin{array}{l}-27.9465^{* * *} \\
(7.9599)\end{array}$ & $\begin{array}{l}-23.0478^{* * *} \\
(8.1081)\end{array}$ \\
\hline $\begin{array}{l}\text { Population } \\
\text { density }\end{array}$ & $\begin{array}{l}-0.0175 \\
(0.0290)\end{array}$ & $\begin{array}{l}0.0743 \\
(0.2205)\end{array}$ & $\begin{array}{l}0.0727 \\
(0.2260)\end{array}$ & $\begin{array}{l}-0.0168 \\
(0.0297)\end{array}$ & $\begin{array}{l}0.1052^{*} \\
(0.0592)\end{array}$ & $\begin{array}{l}0.0996^{*} \\
(0.0558)\end{array}$ \\
\hline Educational level & $\begin{array}{l}-0.3774^{* * *} \\
(0.1352)\end{array}$ & $\begin{array}{l}1.0807 \\
(0.7505)\end{array}$ & $\begin{array}{l}1.0247 \\
(0.7733)\end{array}$ & $\begin{array}{l}-0.2453 \\
(0.1545)\end{array}$ & $\begin{array}{l}0.4281 \\
(0.2720)\end{array}$ & $\begin{array}{l}0.3295 \\
(0.2735)\end{array}$ \\
\hline $\begin{array}{l}\text { Economic } \\
\text { development } \\
\text { level }\end{array}$ & $0.1254(0.2172)$ & $\begin{array}{l}-2.7548^{* *} \\
(1.1235)\end{array}$ & $\begin{array}{l}-2.7474^{*} \\
(1.4428)\end{array}$ & $\begin{array}{l}-0.0003 \\
(0.2714)\end{array}$ & $\begin{array}{l}-1.1043^{* * *} \\
(0.3858)\end{array}$ & $\begin{array}{l}-1.1373^{* * *} \\
(0.3839)\end{array}$ \\
\hline $\begin{array}{l}\text { Minimum wage } \\
\text { standard }\end{array}$ & $\begin{array}{l}-0.5425^{* * *} \\
(0.2025)\end{array}$ & $\begin{array}{l}2.6156^{* *} \\
(1.0547)\end{array}$ & $\begin{array}{l}2.5369^{* *} \\
(1.2097)\end{array}$ & $\begin{array}{l}-0.4750^{* *} \\
(0.2263)\end{array}$ & $\begin{array}{l}0.8021^{*} \\
(0.4212)\end{array}$ & $\begin{array}{l}0.6033 \\
(0.3719)\end{array}$ \\
\hline $\begin{array}{l}\text { Proportion of } \\
\text { fiscal revenue }\end{array}$ & $\begin{array}{l}-3.5249^{* * *} \\
(1.2360)\end{array}$ & $\begin{array}{l}-9.3368 \\
(7.2345)\end{array}$ & $\begin{array}{l}-10.0404 \\
(7.6272)\end{array}$ & $\begin{array}{l}-4.0176^{* * *} \\
(1.9842)\end{array}$ & $\begin{array}{l}-1.2939 \\
(2.4633)\end{array}$ & $\begin{array}{l}-3.4162^{*} \\
(1.9060)\end{array}$ \\
\hline Inverse Mills ratio & & $\begin{array}{l}-0.2031 \\
(0.9772)\end{array}$ & & & $\begin{array}{l}-0.5720^{* *} \\
(0.2603)\end{array}$ & \\
\hline Goodness of fit & & & 0.0442 & & & 0.1588 \\
\hline Sample size & 7938 & 7938 & 977 & 8037 & 8037 & 1076 \\
\hline $\begin{array}{l}\text { Size of samples } \\
\text { not deleted }\end{array}$ & & 977 & & & 1076 & \\
\hline
\end{tabular}

"**," "**," and "***" represented significance levels of $10 \%, 5 \%$, and $1 \%$, respectively; the numbers in brackets were robust standard errors of estimated coefficients

indicating that entrepreneurial families employ more labor forces in regions with higher informatization levels. In addition, the estimated coefficient of inverse Mills ratio passes the $5 \%$ significance test, indicating that it is significantly not zero and thus it is valid to apply the Heckman two-stage model in studying the informationization and entrepreneurial employment effect. In order to compare with the estimation results from the Heckman two-stage model, column (6) reports the estimation results of informationization and entrepreneurial employment effect based on the ordinary least squares method. The estimation results show that informationization could significantly increase the number of people employed by entrepreneurial families, and the conclusion is consistent with the finding obtained from the Heckman two-stage model. 


\section{Conclusion and policy implications}

\section{Conclusion}

In spite of the arrival of information age, there is little literature that systematically explores the influence of informatization on entrepreneurship. This paper systematically studies this subject based on "2011 China Household Finance Survey" conducted by Southwestern University of Finance and Economics and the Report of China Informationization Development Assessment (2013) released by the China Center for Information Industry Development. The conclusion is that informationization plays a significant role in promoting entrepreneurship. This research conclusion is still robust after considering the endogenous problem, informationization index metrics, econometric model, and research sample. This paper then decomposes informationization into information infrastructure, government informationization, resident informationization, and enterprise informationization and studies their influences on entrepreneurship. It finds that information infrastructure, government informationization, and resident informationization could promote resident entrepreneurship, yet enterprise informationization inhibited it. This paper also goes further to discuss the heterogeneous influences of informationization on entrepreneurship. Compared with corporate entrepreneurship, self-employed entrepreneurship is influenced by informationization better and more significantly. Compared with entrepreneurship in domestic service and productive service industries, informationization promotes resident entrepreneurship more significantly in secondary industries. Finally, the research on informationization and entrepreneurial performance points out that informationization could help achieve the income and employment effects of entrepreneurship.

There are some shortcomings in the research of this paper. Since China Household Finance Survey can provide abundant information about family entrepreneurship, the paper adopts this dataset for our study. However, China Household Finance Survey offers cross-section data that may lead to inaccurate estimation results due to missing time factor. Although we have used the China Family Panel Studies in 2011, 2013, and 2015 for robustness test, we are unable to adopt the database for research to consider the time factor due to the lack of information in other parts of the study. Therefore, we need to use panel data to reassess the influence of informationization on entrepreneurship in future research.

\section{Policy implications}

Some policy implications can be drawn from the research conclusion herein.

Firstly, the government should strengthen its own informationization construction, reform and upgrade various information management systems in accordance with unified norms and standards, establish an information sharing exchange platform to promote wide sharing and effective application of information among government departments, and reduce the degree of control and improve service levels to encourage mass entrepreneurship.

Secondly, since informationization has a significant role in promoting entrepreneurship in secondary industries, government departments should strengthen the planning and arrangement of industrial Internet infrastructure construction, and build an industrial Internet with low latency, high reliability, and wide coverage. They should also 
speed up the deployment and construction of fiber optic networks, mobile communication networks, and wireless local area networks in areas with manufacturing clusters to achieve information network broadband upgrade.

Thirdly, the reform of administrative management system needs to coordinate with informationization to fully exploit the role of informationization in promoting entrepreneurship in productive service industries. Government departments should relax or cancel unnecessary market access administrative approval regulation over producer service industries, encourage and guide private capital to enter industries and fields that are not prohibited explicitly by laws and regulations, and try to create a market environment of fair competition and equal access.

Fourthly, enterprise informationization construction improves the market competitiveness of incumbent enterprises on the one hand and raises the threshold of entrepreneurship on the other hand. To resolve this dilemma, the government should establish and improve informationization service platforms for enterprises to help new ventures improve their informationization level.

\section{Additional file}

Additional file 1 The empirical data. (DTA $832 \mathrm{~kb}$ )

\section{Acknowledgements}

Not applicable.

\section{Authors' contributions}

LZ participated in the design of the study, performed the statistical analysis, and drafted the manuscript. WJ provided the empirical data and helped to draft the manuscript. ZT participated in its design. All authors read and approved the final manuscript.

\section{Funding}

Project funded by China Postdoctoral Science Foundation (grant numbers 2017 M622988).

Availability of data and materials

In order to be able to repeat the findings of this paper, the dataset is available from the corresponding author.

\section{Competing interests}

The authors declare that they have no competing interests.

\section{Author details}

${ }^{1}$ School of Public Affairs and Administration, University of Electronic Science and Technology of China, Chengdu 611731, People's Republic of China. ${ }^{2}$ School of International Business, Southwestern University of Finance and Economics, Chengdu 611130, People's Republic of China.

Received: 1 February 2019 Accepted: 9 July 2019

Published online: 19 July 2019

References

Acs, Z. J., Desai, S., \& Hessels, J. (2008). Entrepreneurship, economic development and institutions. Small Business Economics, $31(3), 219-234$.

Aldrich, H. E., \& Cliff, J. E. (2003). The pervasive effects of family on entrepreneurship: Toward a family embeddedness perspective. Journal of Business Venturing, 18(5), 573-596.

Asongu, S., Nwachukwu, J. C., \& Orim, S. I. (2018). Mobile phones, institutional quality and entrepreneurship in sub-Saharan Africa. Technological Forecasting and Social Change, 131, 183-203.

Asongu, S. A., \& Nwachukwu, J. C. (2018). Openness, ICT and entrepreneurship in sub-Saharan Africa. Information Technology \& People, 31(1), 278-303.

Audretsch, D., \& Keilbach, M. (2004). Entrepreneurship capital and economic growth performance. Regional Studies, 38(8), 949-959.

Audretsch, D. B., Heger, D., \& Veith, T. (2015). Infrastructure and entrepreneurship. Small Business Economics, 44(2), 219-230.

Barnett, W. A., Hu, M., \& Wang, X. (2019). Does the utilization of information communication technology promote entrepreneurship: Evidence from rural China. Technological Forecasting and Social Change, 141, 12-21.

Bosma, N., Content, J., Sanders, M., \& Stam, E. (2018). Institutions, entrepreneurship, and economic growth in Europe. Small Business Economics, 51(2), 483-499. 
Brunello, G., \& Langella, M. (2016). Local agglomeration, entrepreneurship and the 2008 recession: Evidence from Italian industrial districts. Regional Science and Urban Economics, 58, 104-114.

Carree, M. A. \& Thurik, A. R. (2005). The impact of entrepreneurship on economic growth. In Handbook of Entrepreneurship Research (pp. 437-471).

Chai, S., Chen, Y., Huang, B., \& Ye, D. (2018). Social networks and informal financial inclusion in China. Asia Pacific Journal of Management, 35(1), 1-35.

Chowdhury, F, Audretsch, D. B., \& Belitski, M. (2019). Institutions and entrepreneurship quality. Entrepreneurship Theory and Practice, 43(1), 51-81.

Cramer, J. S., Hartog, J., Jonker, N., \& Praag, C. M. V. (2002). Low risk aversion encourages the choice for entrepreneurship: An empirical test of a truism. Journal of Economic Behavior \& Organization, 48(1), 29-36.

Cumming, D., \& Johan, S. (2010). The differential impact of the internet on spurring regional entrepreneurship. Entrepreneurship Theory and Practice, 34(5), 857-883.

Darnihamedani, P., Block, J. H., Hessels, J., \& Simonyan, A. (2018). Taxes, start-up costs, and innovative entrepreneurship. Small Business Economics, 51(4), 355-369.

Das, A., \& Das, S. S. (2015). Online government services and setting up business: Evidence from panel data. Journal of Applied Measurement, 9(3), 200-210.

Djankov, S., Ganser, T., McLiesh, C., Ramalho, R., \& Shleifer, A. (2010). The effect of corporate taxes on investment and entrepreneurship. American Economic Journal: Macroeconomics, 2(3), 31-64.

Ghani, E., Kerr, W. R., \& O'connell, S. (2014). Spatial determinants of entrepreneurship in India. Regional Studies, 48(6), 1071-1089.

Gillett, S. E., Lehr, W. H., Osorio, C. A., \& Sirbu, M. A. (2006). Measuring broadband's economic impact. In Massachusetts Institute of Technology Engineering Systems Division Working Papers Series.

Hanoteau, J., \& Rosa, J. (2019). Information technologies and entrepreneurship. Managerial and Decision Economics, 40(2), 200-212.

Heckman, J. J. (1979). Sample selection bias as a specification error. Econometrica, 47(1), 153-161.

Holcombe, R. G. (1998). Entrepreneurship and economic growth. Quarterly Journal of Austrian Economics, 1(2), 45-62.

Hvide, H. K., \& Panos, G. A. (2014). Risk tolerance and entrepreneurship. Journal of Financial Economics, 111(1), 200-223.

Islam, A. (2015). Entrepreneurship and the allocation of government spending under imperfect markets. World Development, $70,108-121$.

Kolko, J. (2012). Broadband and local growth. Journal of Urban Economics, 71(1), 100-113.

Magri, S. (2011). Household wealth and entrepreneurship: Is there a link? In Bank of Italy Temi di Discussione Working Paper.

Martin, L. M., \& Wright, T. L. (2005). No gender in cyberspace? Empowering entrepreneurship and innovation in female-run ICT small firms. International Journal of Entrepreneurial Behavior \& Research, 11(2), 162-178.

Martin, M. A. G., Picazo, M. T. M., \& Navarro, J. L. A. (2010). Entrepreneurship, income distribution and economic growth. International Entrepreneurship and Management Journal, 6(2), 131-141.

Mathew, V. (2010). Women entrepreneurship in Middle East: Understanding barriers and use of ICT for entrepreneurship development. International Entrepreneurship and Management Journal, 6(2), 163-181.

McQuaid, R. W. (2002). Entrepreneurship and ICT industries: Support from regional and local policies. Regional Studies, 36(8), 909-919.

Motilewa, D. B., Onakoya, O. A., \& Oke, A. O. (2015). ICT and gender specific challenges faced by female entrepreneurs in Nigeria. International Journal of Business and Social Science, 6(3), 97-105.

Mueller, P. (2006). Exploring the knowledge filter: How entrepreneurship and university- industry relationships drive economic growth. Research Policy, 35(10), 1499-1508.

Nambisan, S. (2016). Digital entrepreneurship: Toward a digital technology perspective of entrepreneurship. Entrepreneurship Theory and Practice, 41(6), 1029-1055.

Paulson, A. L., \& Townsend, R. (2004). Entrepreneurship and financial constraints in Thailand. Journal of Corporate Finance, 10(2), 229-262

Pistrui, D., Huang, W., Oksoy, D., Jing, Z., \& Welsch, H. (2010). Entrepreneurship in China: Characteristics, attributes, and family forces shaping the emerging private sector. Family Business Review, 14(2), 141-152.

Prieger, J. E., Bampoky, C., Blanco, L. R., \& Liu, A. (2016). Economic growth and the optimal level of entrepreneurship. World Development, 82, 95-109.

Prieger, J. E., Lu, H., \& Zhang, H. (2017). The importance of transportation, broadband, and intellectual infrastructure for entrepreneurship. In Pepperdine University, School of Public Policy Working Papers.

Prljić, S., Vučeković, M., \& Vujačić, S. (2015). The importance of information and communication technologies in the development of women entrepreneurship. Journal of Women's Entrepreneurship and Education, (3-4), 65-76.

Renzulli, L. A., Aldrich, H., \& Moody, J. (2000). Family matters: Gender, networks, and entrepreneurial outcomes. Social Forces, 79(2), 523-546.

Stam, E., \& van Stel, A. (2009). Types of Entrepreneurship and Economic Growth. In UNU- MERT Working Papers.

Valliere, D., \& Peterson, R. (2009). Entrepreneurship and economic growth: Evidence from emerging and developed countries. Entrepreneurship \& Regional Development, 21(5-6), 459-480.

Van der Sluis, J., Van Praag, M., \& Vijverberg, W. (2008). Education and entrepreneurship selection and performance: A review of the empirical literature. Journal of Economic Surveys, 22(5), 795-841.

Wennekers, S., Wennekers, A. V., Thurik, R., \& Reynolds, P. (2005). Nascent entrepreneurship and the level of economic development. Social Science Electronic Publishing, 24(3), 293-309.

Wong, P. K., Ho, Y. P., \& Autio, E. (2005). Entrepreneurship, innovation and economic growth: Evidence from GEM data. Small Business Economics, 24(3), 335-350.

Yueh, L. (2009). China's entrepreneurship. World Development, 37(4), 778-786.

Zhang, C., Xu, Q., Zhou, X., Zhang, X., \& Xie, Y. (2014). Are poverty rates underestimated in China? New evidence from four recent surveys. China Economic Review, 31(9), 410-425.

Zhang, F., \& Li, D. (2018). Regional ICT access and entrepreneurship: Evidence from China. Information \& Management, 55(2), 188-198.

\section{Publisher's Note}

Springer Nature remains neutral with regard to jurisdictional claims in published maps and institutional affiliations. 